\title{
SISTEM INFORMASI AKUNTANSI PADA KINERJA USAHA KECIL MENENGAH
}

\author{
NANIK ERMAWATI \\ NURUL RIZKA ARUMSARI
}

\author{
Universitas Muria kudus, Jalan Lingkar Utara UMK Gondangmanis, Bae, Kudus Jawa Tengah, Indonesia \\ nanik.ermawati@umk.ac.id, nurul.rizka@umk.ac.id
}

\begin{abstract}
The performance of Small and Medium Enterprises (UKM) is the overall success achieved by SMEs, which can be seen from the increase in sales, increase in profit, increase in working capital, and increase in operating profit. It is so important the performance of UKM for the survival of UKM. Therefore, this study examines the performance of SMEs in Kudus Regency with the research population being all SMEs in Kudus Regency. The sampling technique used in this study was purposive sampling technique with a total sample of 94 respondents who can be processed. The data analysis technique used is multiple regression analysis techniques. The results showed that: 1). Understanding of accounting information, application of information systems, entrepreneurial skills do not affect the performance of SMEs, 2). Accounting knowledge has a positive effect on the performance of SMEs.
\end{abstract}

Keywords: Performance, accounting information systems, application of accounting information systems, accounting knowledge

\begin{abstract}
Abstrak: Kinerja Usaha Kecil Menengah (UKM) merupakan keberhasilan secara menyeluruh yang diraih oleh UKM yang dapat dilihat dari kenaikan penjualan, kenaikan laba, kenaikan modal usaha, kenaikan laba usaha. Begitu penting kinerja UKM demi kelangsungan hidup UKM. Oleh karena itu penelitian ini menguji kinerja UKM di Kabupaten Kudus dengan populasi penelitian adalah seluruh UKM di Kabupaten Kudus. Teknik sampling yang digunakan dalam penelitian ini menggunakan teknik purposive sampling dengan total sampel yang dapat diolah sebanyak 94 responden. Teknik analisis data yang digunakan adalah teknik analisis regresi berganda. Hasil penelitian menunjukkan bahwa : 1). Pemahaman informasi akuntansi, penerapan sistem informasi, kemampuan berwirausaha tidak berpengaruh terhadap kinerja UKM, 2). Pengetahuan akuntansi berpengaruh positif terhadap kinerja UKM.
\end{abstract}

Kata kunci: Kinerja, sistem informasi akuntansi, penerapan sistem informasi akuntansi, pengetahuan akuntansi

\section{PENDAHULUAN}

Keberlangsungan usaha UKM saat ini dapat dilihat dari bagaimana UKM mampu dan eksis dalam kondisi yang tidak pasti. Kondisi yang tidak pasti saat ini disebabkan karena adanya pandemi Covid 19 dimana pandemi ini menyebabkan semua perekonomian tersendat karena semua warga masyarakat diharapkan untuk melakukan aktivitas yang terbatas. Kondisi seperti ini sangat berdampak bagi UKM terkait dengan bagaimana penjualan UKM, bagaimana laba UKM. Pastinya penjualan UKM ini mengalami penurunan. Kondisi yang seperti ini menunjukkan Kinerja UKM yang menurun (Mokodompit et al., 2019). 
Kondisi perekonomian UKM di Kabupaten Kudus khususnya ini juga mengalami dampak yang luar biasa karena Kudus juga termasuk zona merah. Berdasarkan data dari Waluyo (2020) selaku Kepala Dinas Tenaga Kerja Perindustrian Koperasi Usaha Kecil dan Menengah Kabupaten Kudus, sejumlah 2.538 pekerja di Kabupaten Kudus pada bulan Mei 2020 dirumahkan, sebagai dampak penurunan produksi. Hal ini menunjukkan bahwa Kinerja UKM mengalami penurunan. Data terkait penurunan Kinerja UKM juga di dukung oleh hasil survey yang telah dilakukan oleh Lembaga IImu Pengetahuan Indonesia (LIPI). Berdasarkan survei yang telah dilakukan oleh LIPI (2020) pada bulan Mei 2020 terkait dengan KinerjaUKM akibat dampak Covid 19 sebagai berikut:

Tabel 1 Temuan LIPI sebagai Dampak Covid 19 (LIPI, 2020)

\begin{tabular}{lcc}
\hline Keterangan & Responden & $\begin{array}{c}\text { Penurunan } \\
\text { Penjualan }\end{array}$ \\
\hline Usaha Mikro & $54,98 \%$, & $49,01 \%$ \\
Ultra-Mikro & $33,02 \%$, & $43,3 \%$ \\
Pelaku & $8,1 \%$ & $40 \%$ \\
Usaha Kecil & & \\
Usaha & $3.89 \% ;$ & $45,83 \%$ \\
Menengah & & \\
\hline
\end{tabular}

Secara garis besar dari tabel $1 \mathrm{di}$ atas menunjukkan bahwa pelaku UKM memang mengalami penurunan penjualan yang drastis. Penurunan penjualan ini jika terus terjadi akan mengakibatkan tutupnya UKM ini karena UKM ini tidak mampu untuk menutup biaya biaya yang dikeluarkan selama masa pandemi ini. Oleh karena itu ada beberapa faktor yang harus diperhatikan terkait dengan KinerjaUKM ini supaya UKM bisa menjalankan bisnisnya dengan lancar.

Salah satu faktor yang mempengaruhi Kinerja UKM ini adalah pemahaman sistem informasi akuntansi. Menurut Endiana \& Sudiartana (2016) pemahaman sistem informasi akuntansi memiliki peran penting bagi keberlangsungan usaha karena sistem informasi akuntansi ini memberikan informasi yang tepat bagi UKM. UKM memahami betul bahwa penggunaan teknologi dalam memproses data untuk menghasilkan laporan laba rugi akan sangat membantu sehingga terjadi efektivitas dalam berbisnis. Efektivitas dalam berbisnis inilah yang bisa disebut dengan Kinerja UKM. Hasil penelitian ini sejalan dengan penelitian yang telah dilakukan oleh Endiana \& Sudiartana (2016), Imbayani \& Endiana (2016), Albab (2017). Namun hasil penelitian ini tidak sejalan dengan penelitian yang telah dilakukan oleh Umiyati (2013).

Faktor kedua yang mempengaruhi Kinerja UKM adalah penerapan sistem informasi akuntansi. Penerapan sistem informasi akuntansi merupakan implementasi dari penggunaan teknologi informasi dalam menjalankan bisnisnya. Ketika UKM paham tentang sistem informasi akuntansi, maka UKM akan mengimplementasikan sistem tersebut dalam menjalankan bisnisnya (Endiana \& Sudiartana, 2016). Penerapan sistem informasi akuntansi ini akan memudahkan UKM dalam melaksanakan operasional perusahaannya, sehingga Kinerja UKM akan meningkat. Hasil penelitian ini sejalan dengan penelitian yang telah dilakukan oleh Imbayani \& Endiana (2016), Wahyuni et al., (2018), Indralesmana \& Suaryana (2014) yang menunjukkan bahwa penerapan sistem informasi akuntansi berpengaruh terhadap Kinerja UKM. Namun hasil penelitian ini tidak sejalan dengan hasil penelitian yang telah dilakukan oleh Endiana \& Sudiartana (2016) yang menemukan bukti bahwa penerapan sistem informasi akuntansi ini tidak berpengaruh terhadap KinerjaUKM. 
Faktor ketiga yang mempengaruhi Kinerja UKM adalah pengetahuan akuntansi. Pengetahuan akuntansi merupakan seberapa jauh ilmu yang dimiliki UKM dalam menghitung untung ruginya usaha yang dijalankan (Abdillah et al., 2019). Menurut (Mukhlisiah et al., 2016) menemukan bukti bahwa UKM yang mampu memahami bagaimana menghasilkan laporan keuangan untuk keberlanjutan usahanya ini akan meningkatkan Kinerja UKM. UKM yang mampu menentukan untung ruginya sebuah usahanya dengan baik dapat diindikasikan Kinerja UKM nya bagus, karena UKM ini akan berusaha untuk memperoleh keuntungan yang setinggi tinggi nya dengan mengeluarkan biaya yang efektif. Hal ini sejalan dengan penelitian yang telah dilakukan oleh Fahrianta et al. (2013), Abdillah et al. (2019), Firdayanti et al. (2020), Lestari \& Rustiana (2019) yang menemukan bukti bahwa pengetahuan akuntansi berpengaruh terhadap KinerjaUKM. Namun hasil penelitian ini tidak sejalan dengan hasil penelitian yang telah dilakukan oleh Wahyuni et al. (2018) yang menemukan bukti bahwa pengetahuan akuntansi tidak berpengaruh terhadap KinerjaUKM.

Faktor keempat yang mempengaruhi Kinerja UKM adalah kemampuan berwirausaha. Menurut Lanang et al. (2014) kemampuan berwirausaha adalah seberapa jauh kemampuan yang dimiliki oleh UKM dalam menciptakan perubahan yang bersifat inovatif dalam proses produksinya. UKM yang mampu menciptakan sesuatu yang inovatif dan kreatif akan memberikan nilai tambah bagi UKM, sehingga UKM ini akan lebih maju dalam bisnis. Dengan majunya bisnis yang dimilikinya ini merupakan indikator Kinerja UKM meningkat. Hasil penelitian ini sejalan dengan penelitian yang telah dilakukan oleh Lanang et al. (2014), Fahrianta et al. (2013) yang menemukan bukti bahwa kemampuan berwirausaha berpengaruh terhadap Kinerja UKM. Namun hasil penelitian ini tidak sejalan dengan hasil penelitian yang dilakukan oleh Mukhlisiah et al. (2016) yang menyatakan bahwa kemampuan berwirausaha tidak berpengaruh terhadap KinerjaUKM.

Penelitian ini merupakan replikasi dari penelitian yang telah dilakukan oleh Imbayani \& Endiana (2016). Perbedaan penelitian ini dengan sebelumnya yaitu dengan menambah dua variabel independen yaitu pengetahuan akuntansi dan kemampuan berwirausaha. Pengetahuan akuntansi merupakan faktor penting untuk menentukan keberlangsungan usaha sehingga sangat penting juga untuk menilai Kinerjasebuah UKM (Firdayanti et al., 2020). Sedangkan kemampuan berwirausaha juga merupakan faktor penting dalam menentukan sukses tidaknya sebuah usaha (Lanang et al., 2014). Jika UKM tidak inovatif dalam berbisnis maka akan kalah dengan UKM yang lainnya.

\section{Teori Knowledge Based View}

Teori Knowledge Based View (KBV) adalah teori yang mendasarkan bahwa kesuksesan sebuah bisnis atau usaha ini dimulai dari seberapa jauh pengetahuan yang dimiliki oleh perusahaan dalam operasional kegiatan usahanya (Curado \& Bontis, 2006). Jika kegiatan bisnis ini dijalankan dengan pengetahuan yang maksimal, maka akan menghasilkan Kinerja yang bagus, perusahaan akan memperoleh tujuannya yaitu memperoleh pendapatan yang tinggi (Cheng et al., 2010). Begitu pentingnya pengetahuan bagi kesuksesan sebuah bisnis, maka pengetahuan ini wajib dimiliki oleh sebuah UKM. Sukses tidaknya sebuah bisnis pun juga di pengaruhi oleh seberapa jauh pengetahuan yang dimiliki oleh pelaku bisnis itu sendiri (Curado \& Bontis, 2006).

\section{Kinerja UKM}

Kinerja UKM adalah seberapa besar prestasi yang diraih oleh UKM dalam 
menjalankan bisnisnya yang diukur berdasarakan perbandingan dengan beberapa standar (Lanang et al., 2014). Menurut Subroto et al. (2016) mengindikasikan bahwa Kinerja UKM dapat dilihat dari sisi UKM memiliki nilai tambah yaitu menyumbang Penerimaan Domestik Bruto (PDB), memiliki unit bisnis yang banyak, memiliki tenaga kerja yang cukup tinggi, UKM mampu untuk mengekspor usahanya. Sedangkan menurut Endiana \& Sudiartana (2016) Kinerja UKM dapat dilihat dari sisi Leadership, Strategic Planning, Customers Focus, Measurement, Analysis, and Knowledge Management, Workforce Focus, Operation Focus, Organizational Performance Result. Dapat disimpulkan bahwa Kinerja UKM adalah hasil kerja dari UKM dimana pencapaian kerja nya itu dapat dilihat dari segala aspek yaitu dari sisi kepemimpinan, memiliki tenaga kerja yang cukup tinggi, mampu memenuhi kebutuhan pelanggan, memiliki tingkat pengetahuan yang tinggi, menghasilkan pendapatan yang tinggi, mampu memproduksi produk yang berkualitas.

\section{Pemahaman Sistem Informasi Akuntansi}

Pemahaman sistem informasi akuntansi merupakan sebuah pengetahuan yang dimiliki oleh UKM bahwa sistem informasi itu penting bagi UKM. UKM harus memahami bahwa dalam menjalankan bisnis harus diimbangi dengan teknologi demi kelancaran bisnisnya (Endiana \& Sudiartana, 2016). Berdasarkan teori Konwledge Based View (KBV), yang menjelaskan bahwa pengetahuan sangat penting bagi keberlangsungan usaha. Pengetahuan yang dimaksud adalah pengetahuan terkait dengan pemahaman sistem informasi akuntansi. Dengan pemahaman UKM terkait pentingnya sistem informasi akuntansi ini akan menghasilkan efektivitas penjualan. Misalnya dalam transaksi penjualan, dijalankan dengan menggunakan teknologi online, tentunya akan mempermudah dan efisien bagi perusahaan. Efisiensi inilah yang disebut dengan Kinerja UKM. Dengan UKM paham tentang sistem informasi akuntansi akan meningkatkan penjualan.
Dengan kata lain UKM yang paham tentang sistem informasi akuntansi akan meningkatkan Kinerja UKM. Kinerja UKM ini dapat dilihat dari tingginya tingkat penjualan produknya. Menurut Endiana \& Sudiartana (2016), sebagus apapun sistem informasi yang dibuat tetapi jika sumber daya manusia tidak memiliki pengetahuan tentang sistem informasi akuntansi tidak akan menghasilkan apa-apa. Sehingga Kinerja Keuangan UKM tidak akan bagus. Hasil penelitiannya menyatakan bahwa pemahaman sistem informasi akuntansi berpengaruh positif terhadap Kinerja Keuangan UKM. Hasil serupa juga pernah diteliti oleh Prastika \& Purnomo (2014), Wahyuni et al., (2018), Indralesmana \& Suaryana (2014). Berdasarkan logika berpikir dan temuan peneliti terdahulu, oleh karena itu dapat dirumuskan hipotesis penelitian sebagai berikut:

H1: Pemahaman sistem informasi akuntansi berpengaruh positif terhadap Kinerja Keuangan UKM.

\section{Penerapan Sistem Informasi Akuntansi}

Penerapan sistem informasi akuntansi merupakan kelanjutan dari pemahaman sistem informasi akuntansi, dimana jika UMK mini paham betul tentang sistem informasi akuntansi yang mampu memudahkan UKM dalam mengolah informasinya, maka UKM akan mengaplikasikan sistem informasi akuntansi dalam menjalankan bisnisnya. Menurut Endiana \& Sudiartana (2016), menyatakan bahwa penerapan sistem informasi akuntansi dilihat dari seberapa jauh frekeuensi pemakaian sistem informasi akuntansi dalam bertransaksi, semakin banyak frekeuensi pemakaian sistem informasi akuntansi dalam bertransaksi akan menghasilkan kemudahan dan efisiensi bagi perusahaan. Dengan kata lain semakin sering UKM mengimplementasikan sistem informasi akuntansi akan menghasilkan Kinerja Keuangan UKM yang baik. Hal ini juga sejalan dengan teori Knowledge Based View (KBV) dimana pengetahuan sangat penting dalam mengimplementasikan sistem informasi akuntansi. Jika sumber daya manusia nya 
memiliki pengetahuan yang tinggi tentang bagaimana cara mengopersionalkan sistem informasi akuntansi ini maka Kinerja Keuangan UKM akan meningkat. Misalkan UKM akan melakukan transaksi pembelian, dengan menggunakan sistem yang canggih dan diimbangi dengan pengetahuan pengguna yang tinggi maka akan mempercepat proses transaksi. Hal ini akan meningkatkan Kinerja Keuangan UKM. Dengan kemudahan sistem informasi ini akan menghasilkan peningkatan penjualan atau peningkatan Kinerja Keuangan UKM. Begitu pula menurut Albab (2017), penerapan sistem informasi akuntansi berpengaruh terhadap Kinerja Keuangan UKM. Hasil penelitian ini juga didukung dari penelitian yang telah dilakukan oleh Indralesmana \& Suaryana (2014), Imbayani \& Endiana (2016), Endiana \& Sudiartana (2016). Berdasarkan kerangka konseptual tersebut maka dapat dirumuskan hipotesis penelitian sebagai berikut:

$\mathrm{H}$ 2: Penerapan sistem informasi akuntansi berpengaruh positif terhadap Kinerja Keuangan UKM.

\section{Pengetahuan Akuntansi}

Pengetahuan akuntansi sangat penting bagi UKM dalam menentukan untung ruginya sebuah usaha yang dijalankan. Sesuai dengan teori Knowledge Based View, kesuksesan sebuah usaha harus di imbangi dengan tingkat pengetahuan yang tinggi dari UKM. Disini UKM yang memiliki pengetahuan tinggi dalam menyusun laporan keuangan tentunya akan lebih mudah dalam mengambil keputusan. Menurut Farida et al., (2019) jika UKM memiliki pengetahuan tinggi dalam menentukan untung ruginya sebuah usaha yang dijalankannya, tentunya UKM paham betul bagaimana cara meningkatkan penjualan. Dengan meningkatnya penjualan ini mengindikasikan tingginya Kinerja Keuangan UKM. Dengan kata lain semakin tinggi pengetahuan akuntansi yang dimiliki UKM dalam menjalankan bisnisnya maka akan meningkatknya Kinerja Keuangan UMK juga. Hasil penelitian menunjukkan bahwa pengetahuan akuntansi berpengaruh terhadap Kinerja Keuangan UKM pernah diteliti oleh (Lanang et al., 2014, Farida et al., 2019, Utami, 2018, Mukhlisiah et al., 2016, Lestari \& Rustiana, 2019, Firdayanti et al., 2020, Abdillah et al., 2019). Berdasarkan logika berpikir dan hasil temuan yang mendukung, sehingga dapat dirumuskan hipotesis penelitian sebagai berikut:

H3: Pengetahuan akuntansi berpengaruh positif terhadap Kinerja Keuangan UKM.

\section{Kemampuan Berwirausaha}

Kemampuan berwirausaha juga merupakan faktor penting juga dalam menentukan Kinerja Keuangan UKM. Menurut Firdayanti et al., (2020), kemampuan berwirausaha merupakan kemampuan yang dimiliki oleh pengusaha dalam mencari peluang dan ide kreatif dalam menunjang operasional perusahaannya. Menurut Lanang et al., (2014), UKM harus mampu berjuang dalam memperluas usahanya. Dalam memperjuangkan usahanya ini UKM diharapkan memiliki kreatifitas yang tinggi. Untuk mendapatkan kreatifitas yang tinggi ini, UKM harus memiliki tingkat pengetahuan yang tinggi untuk bisa menghasilkan Kinerja Keuangan yang bagus. Sesuai dengan teori Knowledge Based View (KBV), dimana pengetahuan merupakan sumber kesuksesan sebuah usaha. Pengetahuan yang tinggi UKM akan menumbuhkan kemampuan berwirausaha UKM, dengan kemampuan berwirausaha yang tinggi, maka UKM akan semakin kreatif. Kreatifitas UKM ini mampu meningkatkan penjualan UKM. Dapat di indikasikan bahwa Kinerja Keuangan UKM juga ikut meningkat. Hasil penelitian yang mendukung bahwa kemampuan berwirausaha mempengaruhi Kinerja Keuangan UKM pernah diteliti oleh Fahrianta et al., (2013), Firdayanti et al., (2020), Lanang et al., (2014). Berdasarkan uraian di atas maka dapat dirumuskan hipotesis penelitian sebagai berikut:

H4: Kemampuan berwirausaha berpengaruh positif terhadap Kinerja Keuangan UKM

Berikut ini disajikan gambar dari kerangka penelitian sebagai berikut: 


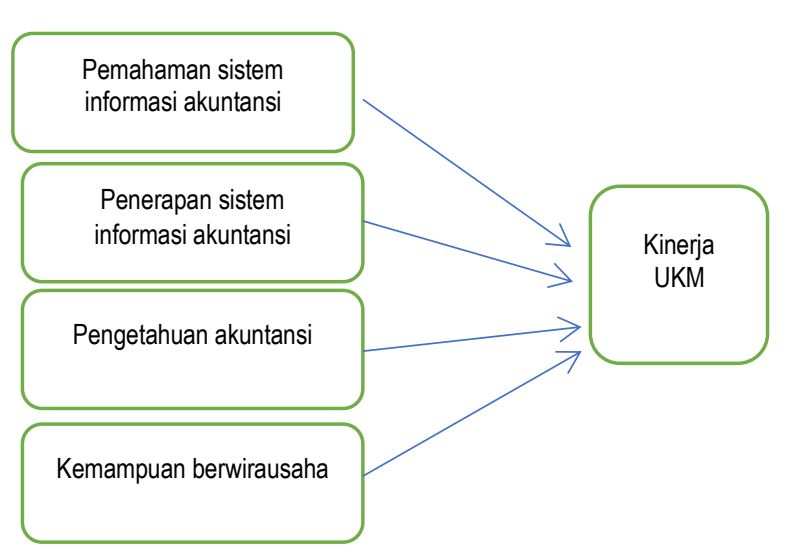

\section{Gambar 1. Kerangka Pemikiran (Imbayani \& Endiana, 2016)}

\section{METODE PENELITIAN}

Populasi dalam penelitian ini adalah seluruh Usaha Mikro Kecil dan Menengah (UKM) Kabupaten Kudus yang berjumlah 13.500 (Dinas Perindustrian Koperasi Dan UMKM Kabupaten Kudus, 2020). Berikut data jenis UKM yang ada di Kabupaten Kudus : Gula Tumbu, Genteng \& Batu Bata, Handy Craft, Kain Bordir, Jilbab, Gebyok \& Ukir, Gerabah, Batik, Tas, Sepatu \& Sandal, Perhiasan, Pakaian, Minuman, Makanan (Dinas Perindustrian, Perdagangan, Koperasi, 2020). Penentuan jumlah sampel menggunakan rumus Slovin (Sanusi, 2017).

Dengan menggunakan rumus sampling dari Slovin menghasilkan 100 responden. Teknik pengambilan sampel menggunakan metode purposive sampling dengan kriteria sebagai berikut : 1). UKM yang telah berdiri lebih dari 1 tahun, 2). UKM yang dimaksud adalah UKM untuk usaha kecil, dengan kriteria berdasarkan undang-undang UKM yang memiliki asset 50 juta sampai dengan 300 juta dan kriteria omzet 300 juta sampai dengan 2,5 Milyar Rupiah. Kuesioner yang kembali sebesar 119 responden, namun terdapat 25 responden yang tidak dapat diolah. Hasil akhir sampel yang dapat digunakan dalam pengujian sebesar 94 responden karena ada data outlier. Indikator variabel

Indikator variabel yang digunakan dalam penelitian ini sebagai berikut:
Tabel 2 Indikator Variabel

\begin{tabular}{|c|c|}
\hline Variabel & Indikator \\
\hline Kinerja UKM & $\begin{array}{lr}\text { peningkatan } & \text { jumlah } \\
\text { produk, peningkatan } \\
\text { laba, } & \text { peningkatan } \\
\text { modal, peningkatan } \\
\text { pelanggan, } & \text { target } \\
\text { laba } & \text { untuk } \\
\text { pengembangan modal } \\
\text { (Rapih, 2015). }\end{array}$ \\
\hline $\begin{array}{l}\text { Pemahaman } \\
\text { Sistem Informasi } \\
\text { Akuntansi }\end{array}$ & $\begin{array}{l}\text { Pentingnya pelatihan } \\
\text { sumber daya manusia, } \\
\text { Computer penting bagi } \\
\text { UKM, Transaksi dengan } \\
\text { data yang lengkap, } \\
\text { Bisnis dismbangi } \\
\text { teknologi, Sumber daya } \\
\text { manusiar mampu } \\
\text { bertransaksi manual dan } \\
\text { elektronik (Endiana \& } \\
\text { Sudiartana, 2016). }\end{array}$ \\
\hline $\begin{array}{l}\text { Penerapan Sistem } \\
\text { Informasi Akuntansi }\end{array}$ & $\begin{array}{lr}\text { karyawan } & \text { sering } \\
\text { mengikuti } & \text { pelatihan, } \\
\text { penggunaan } & \text { transaksi } \\
\text { manual, } & \text { kelengkapan } \\
\text { data } & \text { transaksi, } \\
\text { penggunaan } & \text { software, } \\
\text { penggunaan } & \text { laptop, } \\
\text { komputer } & \text { sangat } \\
\text { membantu } & \text { (Wahyuni et } \\
\text { al., 2018). } & \end{array}$ \\
\hline $\begin{array}{l}\text { Pengetahuan } \\
\text { Akuntansi }\end{array}$ & 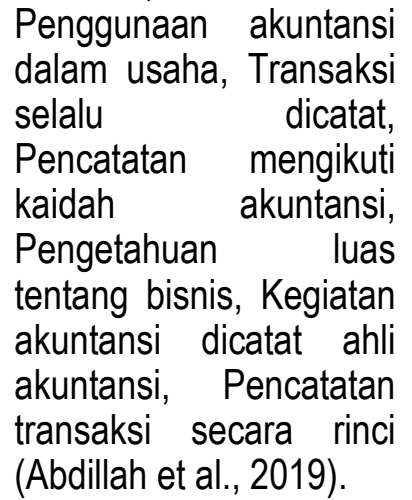 \\
\hline $\begin{array}{l}\text { Kemampuan } \\
\text { Berwirausaha }\end{array}$ & $\begin{array}{l}\text { Mengambil risiko, } \\
\text { Menyukai pekerjaan } \\
\text { yang sesuai ilmu, } \\
\text { Menyukai tantangan, } \\
\text { Jiwa optimism, Menyukai }\end{array}$ \\
\hline
\end{tabular}


tantangan baru,

Menyukai berwirausaha,

Kreatif, Pekerja keras

(Lasmianingsih, 2013).

Sumber: Diolah peneliti (2020)

Uji hipotesis yang digunakan dalam penelitian ini menggunakan metode analisis regresi berganda. Berikut ini persamaan yang digunakan untuk menguji hipotesis:

$Y=a+b 1 X 1+b 2 X 2+b 3 X 3+b 4 X 4+e$

\section{HASIL PENELITIAN}

Berikut ini disajikan hasil uji validitas, uji reliabilitas, dan uji hipotesis:

Tabel 3 Hasil Pengujian Reliabilitas

\begin{tabular}{ccc}
\hline Variabel & Cronbach Alpha & Keterangan \\
\hline X1 & 0,824 & Reliabel \\
X2 & 0,634 & Reliabel \\
X3 & 0,900 & Reliabel \\
X4 & 0,772 & Reliabel \\
Y & 0,867 & Reliabel \\
\hline
\end{tabular}

Sumber: data primer diolah, 2021

Tabel 4 Hasil Pengujian Validitas

\begin{tabular}{ccc}
\hline Variabel & Signifikansi & Keterangan \\
\hline X1 & 0,00 & Valid \\
X2 & 0,00 & Valid \\
X3 & 0,00 & Valid \\
X4 & 0,00 & Valid \\
Y & 0,00 & Valid \\
\hline \multicolumn{2}{l}{ Sumber: data primer diolah, 2021 }
\end{tabular}

Tabel 5 Hasil Uji Multikolonieritas

\begin{tabular}{ccc}
\hline Variabel & Koefisien & Sig \\
\hline X1 & 0,044 & 0,683 \\
X2 & $-0,099$ & 0,389 \\
X3 & 0,172 & 0,031 \\
X4 & 0,141 & 0,086 \\
\hline \multicolumn{3}{l}{ Sumber : data primer diolah, 2021 }
\end{tabular}

Tabel 3 di atas menunjukkan hasil uji reliablitas. Diperoleh hasil nilai cronbach alpha variabel pemahaman sistem informasi akuntansi, penerapan sistem informasi akuntansi, pengetahuan akuntans, kemampuan berwirausaha, kinerja UKM di atas 0,60. Hasil pengujian menunjukkan reliabel. Tabel 4 menunjukkan hasil uji validitas. Uji validitas di ukur dengan dengan melihat nilai signifikansi. Hasil pengujian diperoleh nilai signifikansi kurang dari 0,05. Hasil pengujian ini menunjukkan kuesioner penelitian ini valid.

Hasil pengujian uji multikolonieritas pada tabel 6 diperoleh nilai tolerance kurang dari 1,00 dan nilai VIF tidak lebih dari 10. Hasil pengujian menunjukkan terbebas dari multikolonieritas.

Hasil uji $\mathrm{t}$ digunakan untuk menjawab hipotesis satu sampai dengan hipotesis keempat. Hipotesis pertama dalam penelitian ini ditolak, yaitu pemahaman sistem informasi akuntansi tidak berpengaruh terhadap kinerja keuangan UKM. Hasil pengujian statistic pada tabel 8 diperoleh nilai signifikansi sebesar 0,683 , yang menunjukkan hipotesis di tolak. Pemahaman sistem informasi akuntansi merupakan seberapa jauh UKM memahami penggunaan teknologi berupa komputer untuk mengelola laporan keuangan sehingga tercipta efektifitas bisnis. Namun hasil penelitian ini tidak mampu menjelaskan pengaruh

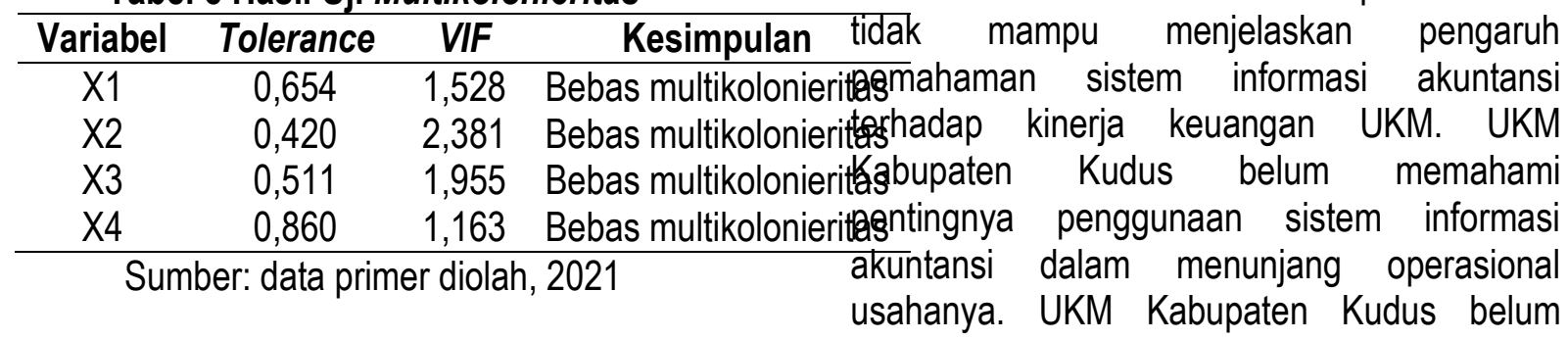


memahami teknologi yang berupa komputer untuk mengelola keuangannya. UKM Kabupaten Kudus lebih menyukai transaksi secara manual misalnya UKM hanya melakukan pencatatan penjualan dan pembelian ke dalam buku catatan. UKM belum menggunakan komputer/laptop untuk memproses data transaksi untuk di olah menjadi sebuah laporan keuangan. Hasil penelitian ini mendukung Endiana \& Sudiartana (2016) sistem informasi yang dirancang dengan bagus namun sumber daya manusia nya belum bisa memahami penggunaan sistem informasi akuntansi tidak menghasilkan kinerja keuangan UKM yang baik.

Hasil penelitian ini juga tidak mendukung Teori Knowledge Based View (KBV). Teori Knowledge Based View (KBV) menunjukkan bahwa bisnis akan sukses jika di imbangi dengan pengetahuan dari sumber daya manusia dari sebuah perusahaan. Hasil penelitian menunjukkan sumber daya manusia UKM Kabupaten Kudus ini memiliki pengetahuan untuk bagaimana mengelola UKM secara manual, namun UKM ini belum mampu memahami pentingnya sistem informasi akuntansi demi efisiensi usahanya sehingga meningkatkan kinerja keuangan UKM. Hasil penelitian ini mendukung penelitian yang telah dilakukan oleh Umiyati (2013). Namun hasil penelitian ini bertolak belakang dengan Endiana \& Sudiartana (2016), Imbayani \& Endiana (2016), Albab (2017).

Hipotesis yang kedua dalam penelitian ini adalah penerapan sistem informasi akuntansi berpengaruh positif terhadap kinerja keuangan UKM. Berdasarkan tabel 8 diperoleh kesimpulan bahwa hipotesis kedua ditolak dengan nilai signifikansi 0,389 yang berarti bahwa penerapan sistem informasi akuntansi tidak berpengaruh terhadap kinerja keuangan UKM. Penerapan sistem informasi akuntansi merupakan tahapan selanjutnya dari pemahaman sistem informasi akuntansi. Sejalan dengan hasil penelitian yang pertama bahwa UKM belum memahami pentingnya pemahaman sistem informasi akuntansi, selanjutnya UKM pastinya belum menerapkan sistem informasi akuntansi. Pengetahuan UKM tentang sistem informasi akuntansi ini memang ada namun UKM nya belum mau menerapkan sistem informasi akuntansi ini dalam menjalankan bisnisnya. UKM merasa kesulitan dalam menggunakan software sistem informasi akuntansi. UKM belum menyadari bahwa bertransaksi dengan menggunakan software sistem informasi akuntansi akan menghasilkan kinerja keuangan UKM. UKM merasa penggunaan software sistem informasi akuntansi ini belum dimanfaatkan sehingga tidak ada pengaruhnya dengan kinerja keuangan UKM. UKM masih menyukai transasksi secara manual misalnya dengan menggunakan nota yang ditulis tangan. UKM masih menggunakan pencatatan manual menggunakan buku kas dalam mencatat transaksi, sehingga UKM belum memiliki laporan keuangan. Hal ini menunjukkan bahwa UKM belum menerapkan sistem informasi akuntansi dalam menjalankan bisnis nya tidak mampu mempengaruhi kinerja keuangan UKM.

Hasil penelitian ini sejalan dengan hasil penelitian yang telah dilakukan oleh Endiana \& Sudiartana (2016). Namun hasil penelitian ini tidak sejalan dengan penelitian yang telah dilakukan oleh Imbayani \& Endiana (2016), Wahyuni et al (2018), Indralesmana \& Suaryana (2014).

Hipotesis ketiga dalam penelitian ini adalah pengetahuan akuntansi berpengaruh positif terhadap kinerja keuangan UMKM. Berdasarkan tabel 8, didapatkan kesimpulan bahwa hipotesis diterima dengan nilai signifikansi 0,031 , hal ini menunjukkan bahwa pengetahuan akuntansi berpengaruh positif terhadap kinerja keuangan UMKM. Hasil penelitian ini sesuai dengan teori Knowledge Based View. Teori menjelaskan bahwa suatu bisnis akan berjalan dengan lancar, ketika bisnis tersebut memiliki sumber daya manusia yang kompeten. Hasil penelitian menunjukkan bahwa tingkat pengetahuan akuntansi yang dimiliki UMKM tinggi. Hal ini dapat dilihat dari UMKM mampu mencatat transaksi ke dalam 
buku besar. Akun-akun kas sudah dicatat sesuai dengan porsinya. UMKM memiliki pegawai khusus yang menangani keuangan UMKM. Dengan keteraturan segi keuangan ini, maka akan meningkatkan kinerja keuangan UMKM. UMKM merasa dengan keuangan yang sudah di catat ke dalam buku besar secara manual ini, dapat digunakan oleh UMKM untuk melihat seberapa besar tingkat keuntungan yang bisa diperoleh UMKM. UMKM memiliki pengetahuan yang luas terhadap kegiatan operasional sehingga mampu meningkatkan kinerja keuangan UMKM.

Hasil penelitian ini sejalan dengan hasil penelitian yang telah dilakukan oleh Fahrianta et al., (2013), Abdillah et al., (2019), Firdayanti et al., (2020), Lestari \& Rustiana (2019). Berbeda dengan Wahyuni et al., (2018) yang menemukan bukti bahwa pengetahuan akuntansi tidak berpengaruh terhadap kinerja keuangan UMKM.

Hipotesis yang keempat dalam penelitian ini adalah kemampuan berwirausaha berpengaruh positif terhadap kinerja keuangan UMKM. Berdasarkan tabel 8 ditemukan bahwa hipotesis keempat ditolak dengan nilai signifikansi sebesar 0,086 , yang menunjukkan bahwa kemampuan berwirausaha tidak berpengaruh terhadap kinerja keuangan UMKM. UMKM yang memiliki ide dan peluang bisnis yang bagus pada saat masa pandemic covid 19 ini, ternyata tidak mampu mempengaruhi kinerja keuangan UMKM. Ketika UMKM yang kreatif dalam menciptakan suatu produk, namun pada saat kondisi ekonomi saat ini yang tidak begitu bagus ternyata tidak mampu menaikkan tingkat penjualan UMKM. Hal ini menunjukkan bahwa UMKM yang memiliki peluang dan ide yang kreatif dalam menciptkan suatu produk saat ini tidak mampu meningkatkan kinerja keuangan UMKM. UMKM sudah berusaha menjadi pekerja keras dalam menjalankan bisnis UMKM, namun jika minat konsumen ini rendah maka tingkat penjualan juga tidak akan ikut naik. Misalkan : usaha di bidang makanan, saat ini mengalami penjualan yang merosot dengan adanya pandemic covid ini karena masyarakat menghindari untuk makan di luar rumah. Hasil penelitian ini menyimpulkan bahwa kemampuan berwirausaha UMKM di Kabupaten Kudus ini tidak mampu mempengaruhi kinerja keuangan UMKM.

Hasil penelitian ini mendukung penelitian yang telah dilakukan oleh Mukhlisiah et al., (2016). Namun hasil penelitian ini tidak sejalan dengan hasil penelitian yang telah dilakukan oleh Fahrianta et al., (2013), Firdayanti et al., (2020), Lanang et al., (2014).

Hasil pengujian uji $\mathrm{F}$ diperoleh nilai signifikansi sebesar 0,018 . Nilai signifikansi 0,018 berarti lebih kecil dari 0,05 sehingga dapat disimpulkan pemahaman sistem informasi akuntansi, penerapan sistem informasi akuntansi, pengetahuan akuntansi, kemampuan berwirausaha berpengaruh secara bersama-sama terhadap kinerja UKM. Hasil pengujian adjusted $\mathrm{R}$ square diperoleh nilai 0,085 . Hasil pengujian menunjukkan $8,5 \%$ sistem pemahaman sistem informasi akuntansi, penerapan sistem informasi akuntansi, pengetahuan akuntansi, kemampuan berwirausaha menggambarkan variasi kinerja UKM, sisanya $91,5 \%$ digambarkan oleh faktor lainnya yang tidak dijelaskan dalam model penelitian ini.

\section{PENUTUP}

Kesimpulan yang dapat diambil dari hasil penelitian ini adalah:

1. Pemahaman sistem informasi akuntansi tidak berpengaruh terhadap kinerja UKM.

2. Penerapan sistem informasi akuntansi tidak berpengaruh terhadap kinerja UKM.

3. Pengetahuan akuntansi berpengaruh positif terhadap kinerja UKM.

4. Kemampuan berwirausaha tidak berpengaruh terhadap kinerja UKM.

\section{Peneliti menyadari banyak} keterbatasan dalam dalam penelitian ini yang terdiri dari:

1. Hasil pengujian Adjusted $R$ Square yang hanya menghasilkan nilai sebesar $8,5 \%$ variabel independen yang mampu 
mempengaruhi variabel kinerja keuangan UMKM.

2. Jumlah responden yang dapat digunakan dalam analisis regresi didapatkan hanya 94 , setelah mengalami outlier data.

Adanya keterbatasan dalam penelitian ini, maka peneliti menyarankan untuk penelitian selanjutnya sebagai berikut:

1. Penelitian selanjutnya dapat menambah faktor lain yang mempengaruhi kinerja keuangan UMKM yaitu tingkat pendidikan (Farida et al., 2019), kemampuan manajerial (Abdillah et al., 2019).

2. Penelitian selanjutnya dapat mengembangkan model penelitian dengan menggunakan structural equation model (Subroto et al., 2016; Farida et al., 2019).

3. Peneliti selanjutnya diharapkan menggunakan metode wawancara sehingga dapat hasil yang lebih akurat.

\section{REFERENCES:}

Abdillah, M., Primasari, D., \& Widianingsih, R. 2019. Pengaruh strategi bisnis, kemampuan manajerial dan pengetahuan akuntansi pelaku umkm terhadap kinerja umkm bidang kuliner di kabupaten purbalingga. Jurnal OPTIMUM, 9(2), 145-157.

Albab, M. U. 2017. Program studi akuntansi fakultas ekonomi universitas muria kudus tahun 2012. Skripsi. , Fakultas Ekonomi \& Bisnis Universitas Muria Kudus.

Cheng, M. Y., Lin, J. Y., Hsiao, T. Y., \& Lin, T. W. 2010. Invested resource, competitive intellectual capital, and corporate performance. Journal of Intellectual Capital, 11(4), 433-450. https://doi.org/10.1108/14691931011085623

Curado, C., \& Bontis, N. 2006. The knowledge-based view of the firm and its theoretical precursor. International Journal of Learning and Intellectual Capital, 3(4), 367-381. https://doi.org/10.1504/IJLIC.2006.011747

Dinas Perindustrian, Perdagangan, Koperasi, dan U. R. (2020). Persebaran Pelaku Usaha Batik Tulis Lasem di Kabupaten Rembang.

Endiana, I. D. M., \& Sudiartana, I. M. 2016. Pengaruh Pemahaman Dan Penerapan Sistem Informasi Akuntansi Terhadap Kinerja Individu Dan Kinerja Umkm Pengrajin Perak I. Jurnal Riset Akuntansi, 6(1), 101983.

Fahrianta, R. Y., Chandra, M., \& Sekolah. 2013. Pengaruh Pengetahuan Akuntansi Dan Kepribadian Wirausaha Terhadap Kinerja Manajerial Pada Perusahaan Dagang Di Kota Banjarmasin. Jurnal Manajemen Dan Akuntansi, 14(April), 1-10.

Farida, I., Sunandar, \& Aryanto. 2019. Faktor-faktor yang berpengaruh terhadap kinerja UMKM di Kota Tegal. Jurnal Monex, 8(2), 79-82.

Firdayanti, F., Diana, N., \& Junaidi. 2020. Pengaruh Pengetahuan Akuntansi Dan Kepribadian Wirausaha 
Terhadap Kinerja Manajerial (Studi pada UMKM Batik Tulis Kabupaten Probolinggo). E-Jra. Fakultas Ekonomi Dan Bisnis Universitas Islam Malang, 09(02), 47-57.

Imbayani, I. G. A., \& Endiana, I. D. M. 2016. Pengaruh Pemahaman Dan Penerapan Sistem Informasi Terhadap Kinerja UMKM Pengrajin Genteng Di Kabupaten Tabanan. Jurnal IImu Manajemen UNIVERSITAS MAHASARASWATI DENPASAR, 6(1).

Indralesmana, K., \& Suaryana, I. 2014. Penerapan Sistem Informasi Akuntansi Dan Kinerja Individu Pada Usaha Kecil Dan Menengah Di Nusa Penida. E-Jurnal Akuntansi, 7(2), 345-356.

Lanang, I. P. E. S., Kirya, I. K., \& Cipta, I. W. 2014. Analisis Faktor-Faktor Yang Mempengaruhi Kinerja Usaha Mikro Kecil Dan Menengah (UMKM) Di Kabupaten Bangli. E-Journal Bisma Universitas Pendidikan Ganesha, 2(1), 11-21.

Lasmianingsih. 2013. Mengukur Tingkat Kemampuan Berwirausaha Mahasiswa. Skripsi. Universitas Gunadarma, $1-28$.

Lestari, N. A., \& Rustiana, S. H. 2019. Pengaruh persepsi owner dan pengetahuan akuntansi dalam penggunaan sistem informasi akuntansi terhadap kinerja usaha mikro, kecil dan menengah di Pamulang. Jurnal of Business and Entrepreneurship, 1(2), 67-80.

LIPI. 2020. Survei Kinerja UMKM di Masa Pandemi COVID19. Biro Kerja Sama, Hukum, Dan Humas LIPI, http://lipi.go.id/berita/survei-kinerja-umkm-di-ma.

Mokodompit, M. P., Syarifuddin, S., \& Mutia, S. 2019. Identifikasi Faktor Yang Mempengaruhi Kinerja Umkm. Jurnal Profita, 12(2), 242. https://doi.org/10.22441/profita.2019.v12.02.005

Mukhlisiah, R., Ethika, \& M, R. Y. 2016. Pengaruh Pengetahuan Akuntansi dan Kepribadian Wirausaha Terhadap Kinerja Manajerial Pada Perusahaan Manufaktur Di Provinsi Sumatra Barat. E Journal Bung Hatta, 4(1), $1-12$.

Prastika, N. E., \& Purnomo, D. E. 2014. Pengaruh Sistem Informasi Akuntansi Terhadap Kinerja Perusahaan Pada Usaha Mikro Kecil Dan Menengah (UMKM) Di Kota Pekalongan. Jurnal Litbang Kota Pekalongan, 7.

Rapih, S. 2015. Analisis Pengaruh Kompetensi Sumber Daya Manusia, Modal Sosial dan Modal Finansial Terhadap Kinerja UMKM Bidang Garmen di Kabupaten Klaten. Tesis, Universitas Sebelas Maret Surakarta.

Sanusi, A. 2017. Metodologi Penelitian Bisnis (7th ed.). Salemba Empat.

Subroto, S., Hapsari, I. M., \& Astutie, Y. P. 2016. Analisis Faktor-Faktor Yang Mempengaruhi Kinerja Usaha Mikro Kecil Dan Menengah (UMKM) Kabupaten Brebes. Prosiding SNaPP: Sosial, Ekonomi Dan Humaniora, 6(1), 337-344.

Umiyati. 2013. Analisis Pengaruh Sistem Informasi Akuntansi Taerhadap Kinerja Keuangan Perusahaan / UMKM di Wilayah BSD Tanggerang Selatan. Ekonomi, Jurnal Borobudur, Universitas, 15(1), 454-456.

Utami, H. T. 2018. Pengaruh Pengetahuan Pemilik, Skala Usaha, dan Umur Usaha terhadap Keberhasilan Kinerja Usaha dengan Penggunaan Informasi Akuntansi sebagai Variabel Moderasi (Survei pada Pemilik Usaha UKM Makanan Khas di Kabupaten Banyumas). El-Jizya : Jurnal Ekonomi Islam, 6(1), 2348. https://doi.org/10.24090/ej.v6i1.2044

Wahyuni, T., Marsdenia, M., \& Soenarto, I. 2018. Analisis Pengaruh Penerapan Sistem Informasi Akuntansi Terhadap Pengukuran Kinerja UMKM di Wilayah Depok. Jurnal Vokasi Indonesia, 4(2). https://doi.org/10.7454/jvi.v4i2.97

Waluyo, B. T. 2020. No Title (p. Dinas Tenaga Kerja Perindustrian Koperasi Usaha Ke). 
